INTERNATIONAL JOURNAL OF ADVANCED RESEARCH IN PUBLIC POLICY, SOCIAL DEVELOPMENT AND ENTERPRISE STUDIES

ISSN Print: 2536-6548

ISSN Online: 2536-6556

Vol. 4 No. 1 March, 2021

Published by

International Scientific Research Consortium

United Kingdom

DOI: 10.48028/iiprds/ijarppsdes.v4.i1

Frequency: Biannually

Open Access Policy: This journal provides immediate open access to its content on the principle of making research freely available to the public supports for a greater global exchange of knowledge.

Disclaimer: The views and ideas expressed in articles / review are those of the authors(s) and not necessarily of the Editorial Board. Articles are published in good faith and the author(s) will be liable for any copyright infringements.

\title{
Editorial Contact
}

International Scientific Research Consortium

Dr. Abdulazeez D. El-Ladan

The Future Institute

10 Coventry Innovation Village

Coventry University

Technology Park, CV1 2TL, United Kingdom

\section{Editorial and Advisory Board}

Prof. Charles Roland

Directorate of Policy and Research

International Scientific Research Consortium, UK

Professor Nathaniel C. Ozigbo

Department of Business Administration

University of Abuja, Nigeria

\section{Professor Kabiru Isa Dandago}

Faculty of Social and Management Sciences

Bayero University, Nigeria

Professor Phil Marpleet

School of Humanities and Social Sciences

University of East London, UK

\section{Ass. Professor Kevin Chas}

Department of Sociology and Social Policy

Lingnan University, Hon Kong

\section{Dr. Arugu O. Love}

Department of Political Science and Strategic Studies

Federal University, Otuoke, NG

\section{Dodo Yakubu Aminu}

Universiti Teknologi Malaysia,

81310 Skudai, Johor Malaysia 
INTERNATIONAL JOURNAL OF ADVANCED RESEARCH IN PUBLIC POLICY, SOCIAL DEVELOPMENT AND ENTERPRISESTUDIES

ISSN Print: 2536-6548ＩSSN Online: 2536-6556

Vol. 4 No. 1 March, 2021

International Directorate of Policy \& Research

c/o Asso. Prof. Diji Chuks

Research, Innovations, Consultancy \& Extension

Kampala International University, Uganda

PT. Hussein Botchway

University of Energy \& Natural Resources

Sunyani, Ghana

ED. Jonah Ulebor

Lextra Education Ltd

Leeds, LS117HL, United Kingdom

admin@internationalpolicybrief.org

\section{Editorial Objectives}

The International Journal of Advanced Research in Public Policy, Social Development and Enterprise Studies (IJARPPSDES) is a peer-reviewed research-driven Journal that provides intellectual platform for the dissemination of critical and empirical research papers in Public Policy, Social Development and Management Sciences. The Journal publishes original reviews, conceptual and empirical issues, as well as policy discourse that affect the framework of nation building, management practices and sustainable development. The articles in the Journal are open access to different countries around the world.

\section{Indexing/Abstracting/Library}

The journal is processed for inclusion in,

- GoogleScholar

- PIAS International Fact Sheets/Achieves

- Ulrich's Periodicals Directory (ProQuest)

- International Bibliography of the Social Sciences (IBSS)

- National Library of Nigeria cataloguing in publication data

- Brilliant International Research Library

Index, author's guidelines, ethics in publishing and ethical guidelines for journal publication see:

http:/ / www.internationalpolicybrief.org/journals

http://www.internationalpolicybrief.org/about-us/peer-review

http:/ / www.elsevier.com/publishingethics

http://www.elsevier.com/journal-authors/ethics

International Copyright Law: All right reserved under the International Copyright Law. This volume is published by the International Scientific Research Consortium UK, in research league with International Institute for Policy Review \& Development Strategies. This journal-its cover page design and content may not be used or produced in any manner without written permission from the International Institute for Policy Review and Development Strategies.

Reference: We accept American Psychological Association (APA) and a double or triple in text citation (Stephen, 2012 or Stephen, 2012:14) 


\section{Contents}

\begin{tabular}{|c|c|c|}
\hline 1 & $\begin{array}{l}\text { New Partnership for African Development and Poverty Reduction in } \\
\text { Nigeria, 2009-2019 } \\
\text { V. C. Onah }\end{array}$ & 1 \\
\hline 2 & $\begin{array}{l}\text { Impact of Promotion on Academic Staff Development in the State } \\
\text { Higher Educational Institutions of Borno State } \\
\text { Aji Abdulmumini }\end{array}$ & 12 \\
\hline 3 & $\begin{array}{l}\text { The Fight Against the Despicable Scourges of Child Trafficking for } \\
\text { Sustainable Development in Nigeria: The Role of the National } \\
\text { Agency for the Prohibition of Trafficking in Persons and other } \\
\text { Related Matters (NAPTIP): A Review of Literature } \\
\text { Abubakar Aminu Boyi }\end{array}$ & 25 \\
\hline 4 & $\begin{array}{l}\text { Corruption and its Effect on National Development: A Case Study } \\
\text { of Nigerian National Petroleum Corporation (2000-2018) } \\
\text { Ishaka Dele }\end{array}$ & 37 \\
\hline 5 & $\begin{array}{l}\text { Enhancing Africa's Internal Security Through Nonviolent } \\
\text { Measures: An Analysis of Nigeria's Amnesty Programme } \\
{ }^{1} \text { John T. Kalama \& }{ }^{2} \text { Johnson Alalibo Sinikiem }\end{array}$ & 51 \\
\hline 6 & $\begin{array}{l}\text { Comparing E-Print and Fedora Digital Library Software: } \\
\text { E-Print or Fedora??? A Better Open Source Repository Platform } \\
\text { for Libraries } \\
{ }^{1} \text { Dikuma Mohammed Ibrahim, }{ }^{2} \text { Muhammad K. Bizi \& }{ }^{3} \text { Ali Usman }\end{array}$ & 63 \\
\hline \multirow[t]{2}{*}{7} & $\begin{array}{l}\text { High-Performance Work Systems, Perceived Organizational } \\
\text { Support and Employee Job Satisfaction of Food Manufacturing } \\
\text { Firms in Port Harcourt }\end{array}$ & \\
\hline & ${ }^{1}$ Ndu Eugene Chigozie \& ${ }^{2}$ Tawiah, Olawumi Debora & 67 \\
\hline 8 & $\begin{array}{l}\text { Effect of Public Debts on Private Sector Investment in Nigeria } \\
{ }^{1} \text { Osuoha, Rophina Chionyeka, }{ }^{2} \text { Udenwa, Theresa A. \& }{ }^{3} \text { Nwala, M. Nneka }\end{array}$ & 96 \\
\hline
\end{tabular}

